\title{
Impact of Export Trade Promotion Organizations on Export Development in Latvia in the Context of Globalization
}

\author{
Vilnis Veinbergs ${ }^{1, *}$, Helena Skadina $^{1}$ \\ ${ }^{1}$ Turība University, Faculty of Business Administration, Department of Commerce, 68 Graudu Street, \\ Riga, Latvia
}

\begin{abstract}
Research background: The impact of globalization in the 21 st century is increasingly bringing change in the world's political, economic, social and technological processes. It has become much easier to get information about relevant events across the borders, which lead to the visibility and accessibility of international business environment. International organizations promote and encourage small countries in the same manner as large ones in order to integrate them into the world's economic development. As a result, most countries become partners and benefit through this globalization process which can be seen as a triggering factor for a successful cross-border trade.

Purpose of the article: This paper aims to analyse the impact of Trade Promotion Organizations (TPO) on business in Latvia and its usefulness for export activities as well as contribution of TPO program to GDP growth in Latvia in the period from 2004 to 2019.

Methods: In this research authors have used a case study method and analysed the experience of TPO in the global trade environment. Secondary data were obtained from statistical databases and research literature; regulations of international organizations in relevant countries - from publicly available sources.

Findings \& Value added: Results of this research indicate that organizations which promote and support Latvian export positively influence activities and high-quality cooperation with exporting companies and entrepreneurs who want to trade abroad. At the end of the research, the authors summarize their findings about TPO's support activities to exporters in Latvia and other countries.
\end{abstract}

Keywords: Trade Promotion Organizations (TPO); Export development; Exporting; Globalization; Latvia.

JEL Classification: $F 13 ; F 23 ; M 16 ; O 43$.

*Corresponding author: vveinbergs@gmail.com 


\section{Introduction}

The effects of globalization create conditions and unlimited opportunities which contribute to accessibility of new markets for doing business. Almost everyone has nowadays the opportunity to buy, sell, obtain and share needed information, study or travel. In Latvia, after regaining of its independence in the 1990s the economic situation of the country - complete economic neglect- became known. The socialism-based economy had to be rapidly reoriented and restructured. In a global context Latvia is a very small country with low and declining population. In 2020, it was $1,907,675$, which is $8 \%$ less than in 2011 [1]. This shows that the quality of life in Latvia is low, but for the Latvian government it is a difficult and responsible task for people to live and work in the country.

Using global environment Latvia has to be able to increase its exports and needs to change its competitiveness strategy from reducing costs to raising the quality level as well as expanding export markets on high-income countries. By obtaining more funds for GNI the state would be able to raise wages and subsequently living standards, which, in turn, would encourage those who have left the country to return. It would be also possible to attract a new labour for the country [2].

Global crisis, including the outbreak because of pandemic in 2020, are forcing change and new challenges for exports. The Bank of Latvia forecasts that due to the consequences of the pandemic in 2020 the volume of Latvia's Gross Domestic Product (GDP) will fall even to $8.5 \%$, but exports will fall to $8.1 \%$, which will significantly affect the volume of GDP.

Exports of goods need to be assessed; export markets must focus on a wide range of services.

Historically and in comparison, to the export of services, which has only grown very recently, exports of goods have gained the most support in cross-border trade. Latvian service sector generates about $65 \%$ of the total added value, which forms a positive overall picture of service exports in the country.

Benefits of globalization, general economic trends, access to education, breadth of knowledge and foreign experience are influential factors for small countries in the context of choosing export promotion priorities. Although there are studies showing that when companies have positive results, entrepreneurs are reluctant to invest in further staff training, they wait for the government to provide it [3]. When developing the TPO implementation program, it is necessary to act in a multifaceted and thoughtful manner, because such an approach would significantly support Latvian companies to trade goods and services abroad. Export policy makers to be review cross-border trade rules in the direction of liberalization, reducing trade barriers that mainly hinder trade in goods - lowering customs tariffs, duties and other barriers to trade [4].

Important to improve skills required by the export-countries, to adhere to a high general standard work culture and to have a favourable and responsive attitude towards the customer. Merchants who, for example, have fewer skills or poor order fulfillment processes (slow delivery, delivery errors, delivery of defective goods, etc.) can create and promote a negative customer experience. Exports cannot be based solely on reducing the cost of goods and services, as this is not always justified, for example, by reducing US export costs, with exports increasing only for smaller sellers [5]. Promoting export of services, in particular, in developing countries, is rarely effective because of significant financial resources which are spent and low direct positive impact on exports. Insufficient resources are also pointed out by other researchers, when large economies offer on average more financial assistance, provide more information, various training [6].

Especially during the preparation phase of export promotion programs of state institutions, the usefulness and efficiency of potentially provided services should be thoroughly studied and considered. Services such as consultancy, information preparation 
and analysis, development of marketing strategies and implementation plans, provision of advertising services, financial support and grants, etc., should as far as possible be based on resource-efficient methods. The importance of TPO contributions and activities is being studied by a large number of researchers at many universities around the world: researchers have concluded that government export promotion programs are an important export driver that stimulates and helps exporting companies to increase export sales. Catanzaro and Teyssier have found that promoting high-quality exports has a positive effect on international performance [7]. However, there are also studies which conclude that national government export promotion does not have a significant impact on exports; such a finding, as the researchers note, may stem from an unsuccessful choice of group of respondents.

What is the export promotion policy of the country? What kind of assistance does the state provide to its entrepreneurs? How are companies supported by trading export goods and services in Latvia or elsewhere in the global environment at all? The authors of this research seek answers to these questions and study the necessity to assess Latvia's GDP and contribution to exports, as well as export support. The ultimate objective of export-promotion policies is not only export growth, but social and economic welfare [8].

\section{Methods}

The aim of the study is to analyse the impact of TPO on Latvian exports, to find out the importance of TPO support in export promotion, relation to the growth of GDP in Latvia in the period 2005-2019 and to identify whether there is value added in supporting and promotional programs in the context of world experience.

The article analyses activities of TPO and their impact on exports of goods and services. Using the case analysis method, the authors examine the impact of Latvia's TPO on business and export support for trading goods and services, as well as analyse the experience of TPO in the global environment. A set of tools and methods of TPO in the global trading environment have been investigated. Secondary data were obtained from statistical databases and scientific literature. At the end of the research, the authors summarize their findings about TPO's support activities to exporters in Latvia and other countries as well as their impact on Latvia's GDP. The results can be used to improve the export support of Latvia and other countries.

\section{Results and Discussion}

\subsection{Theoretical aspects of TPO}

It is very difficult or almost impossible for a low experienced entrepreneur, especially in small or developing countries, to gain a place in the international market. Difficulties are also associated with the costs that the entrepreneur has to bear, and it is often impossible to realize it without support of the state. This means that the state's political position is able to activate or neutralize the export capacity of companies. Some exporters have never asked TPO for help, as they negatively assess the government's ability to help them, do not trust in provided support quality. As the environment of TPO employees is associated with the risk of corruption and information passing to other competitors. In countries, where corruption is rampant, the role of the export promotion organization is low and ineffective. In a seemingly accessible export market beginners are often disappointed because they do not take into account a number of conditions related to export markets when starting to export: information about potential buyers, what they prefer to buy, supply characteristics of potential markets, taxes and customs costs, competitors' technologies, equipment and management systems, etc. 
Many developing countries, in turn, rely on some TPOs. This is due to the fact that export subsidies are not the same for developed and developing countries, high and low GDP countries. These support mechanisms can even vary considerably, as countries with high GDP per capita can invest much more in promoting exports than small economies.

Performance of the TPO may be also negative due to the rigidity of the government structure. About $60 \%$ of all export promotion organizations are formed as public legal entities. Significant export promotion, especially in case of necessary improvements requires policy instruments that are very different from those already in use. Development of exports requires a constant dialogue between policy makers and business community. Promotional services may also need to be provided for a fee by the private sector in competition with a publicly funded service provider. Service charges are means of verifying the adequacy and quality of services and making the best possible use of their resources. Private sector, business associations, public organizations have a major role to play in decision-making.

In a comprehensive study of TPOs in developing countries, D. Keesing and A. Singer acknowledged that government policies in almost all Organisation for Economic Cooperation and Development (OECD) countries are favourable to industrial export and trade promotion organizations, most of which are official governmental organizations. Their main function is usually to provide trade-related information. TPOs should not operate in isolation from the business community. It should be noted that governments, due to their systemic weakness, are hindering the entry of private service providers, especially export of various new technologies because the government is not ready yet, has not standards, e-environment, etc. TPOs could also be involved in design and development of marketing strategies for sectors and products, including all recommended measures and actions to achieve export targets [9]. Poor delivery can quickly undo all export activities. Delivery is always crucial. D. Keesing and A. Singer also concluded that TPO almost always seeks to achieve four key conditions that affect TPO's effectiveness: enjoying the support of business community; adequately funding; working with qualified staff with appropriate and competitive salaries; being independent of the government. A study conducted by Keesing D.B. and Singer (2001) describes an ineffective TPO as well and characterize its present ineffective position.

Some studies have pointed to the reasons for relative failure of TPOs in developing countries: legacy of import substitution policies; lack of attention to supply problems at the company level; lack of donors and funds and small impact of donors; inefficient service delivery mechanisms (TPOs). P. Hogan supplemented it with a poor placement; insufficient human resources; lack of long-term intervention; shortcomings in design and process; bad advice and counsellors. Available financial and human resources are significantly lower than in more developed countries.

Budgetary constraints on exporting companies severely limit the volume of provided services, which can reduce the quality and export performance. These findings can be complemented by six other factors that do not contribute to the public service TPO model: the inadequacy of government staff; inflexibility of government procedures in terms of expenditure and staff; confusion of purpose arising from the adoption of regulatory and administrative roles; maintaining wrong attitudes and strategies; incorrect adjustment; neglect of the development of commercial services [10].

From the above, it can be concluded that there are various TPO factors that hinder the development of exports, both in developing countries and in countries with developed industries and relatively strong economies. In order to promote exports and increase the role of TPOs in business environment, the impact of these factors needs to be reduced or removed.

P. Hogan emphasizes that there is no universally applicable model, however, all successful TPOs have a number of factors in common and these are: organizational autonomy; government and exporter confidence; representation abroad; trained and capable staff; sufficient funding; Range of services provided by TPOs are very wide: commercial 
information; market research; services for foreign buyers; group promotions such as fairs, business trips, exhibitions; transport and transportation consultancy; design and product development; packaging assistance; administration of incentive schemes; licensing and certification; exporter training investment promotion, direct marketing and sales) [11]. Hogan's point is also supported by other researchers and emphasizes that foreign TPOs have a key role to play in developing international trade $[12,13]$. Most of the export promotion organizations in most developed countries have a large number of offices abroad. Such TPOs can be divided into three groups of organizations: with significant number of foreign offices; with limited number of external offices; without a direct representation abroad. The existence and size of a network of foreign offices is always linked to financial resources. The presence of foreign offices in export markets is an important support, such as fairs or trade missions, which can improve a company's export competitiveness [14].

Entrepreneurs' disbelief and doubts about their success in exports make companies reluctant to export. The main reason for this is considered to be the lack of information. Entrepreneurs do not trust in the state's activities in promoting exports, because they think that the state is trying to persuade entrepreneurs to invest time and money in new directions that are unknown to them. This resistance can be overcome in part by high-quality and compelling advertising.

It is known that various types of financial support - grants; additional loans, grants - are positive and encouraging for development of exports, but this fact could also form a so-called "subsidy culture" where exports become dependent on systematic subsidies. The aspect of market choice must also be taken into account, as new competitors emerge in the market at much lower costs from developing countries and gain market share. As a result, high-wage countries have to compete with quality, and Latvia also needs to change its competitiveness strategy from reducing costs to raising quality levels, as well as increasing export markets to high-income countries. The culture of business behavior in the export market is highlighted as an important factor [15].

D.B. Keesing and A. Singer make four key recommendations to help overcome export difficulties: 1) emphasizing support services that help overcome supply difficulties and hinder potentially profitable exports. Advising companies with high export prospects to help them improve supply and performance; 2) providing easy access to suppliers abroad. The development of exports should systematically promote the development of a number of competing service providers in the economy, mainly in the private sector, and facilitate and encourage the establishment of local branches or affiliates of multinational service firms; 3 ) reliance on specific, fixed-term projects or project components related to the import of temporary resources for the purpose of channelling external assistance to services supporting the expansion of industrial exports. Each component of the project must be directed directly to the main goal - to expand exports during the project, avoiding premature and unrealistic institution-building; 4) development of an assistance package developed together with one or more grant funds. These funds provide cost-sharing grants to companies to help cover the cost of services from the suppliers of their choice.

\subsection{TPO in the global environment}

By compiling international trade practices, the World Trade Organization (WTO) develops rules for international trade. The purpose of WTO rules is to help producers, exporters and importers of goods and services to do business and to facilitate trade between countries. The WTO Agreement on Subsidies and Countervailing Measures (ASCM) contains a basic provision that government export credit guarantee operations must continue in the long term. In other words, guarantee premiums must cover all costs. The European Association of Trade Promotion Organizations (ETPOA) was set up with the European TPO from 10 EU Member 
States to engage in trade facilitation negotiations with European institutions and organizations, to support close cooperation between all parties involved in supporting the internationalization of European companies, especially SMEs. Global institutions promote the export of large and small economies. Export success is a favourable export development and promotion policy, well-designed support tools, professional TPO staff.

\subsubsection{The case of the United States}

The United States (US) is the third largest exporter in the world. In the US, exports are the responsibility of the US Commercial Service (USCS). The USCS is an International Trade Promotion Division that aims to promote the export of small and medium-sized businesses, goods and services from the United States; to represent US business interests internationally; to help US companies to find qualified international partners by providing online and customized market research; to support participation in local and foreign exhibitions; to offer contacts with significant buyers and distributors abroad for a fee; to provide individual counselling and legal defence; to lay the foundations for export knowledge, documentation and control mechanisms. Specialists from the USCS International Trade Unit (sales officers, consultants, assistants, and support staff) meet with clients at U.S. export assistance centres as well as USCS offices at U.S. embassies and consulates in more than 150 cities in 80 countries.

\subsubsection{The case of Sweden}

The Secretary of State is responsible for Swedish trade and export promotion, but is chaired by the Minister for Enterprise and Innovation. The state, supporting the export of small and medium-sized enterprises, shares and provides information on exports and internationalization; information on individual export markets; inform about export promotion guarantees and financing solutions; provides contacts with buyers, customers and decision makers; helps to remove bureaucratic barriers in trading. Business Sweden, with more than 50 offices around the world, is an organization that supports and promotes exports in Sweden, it is organized by both the public and private sectors. The Swedish Export Credit Agency (EKA) reports to the Minister of Trade. The task of the Swedish Export Agency $(\mathrm{EKN})$ is to promote Swedish exports. EKN, in cooperation with large global companies, as well as very small ones, guarantees their export business in more than 130 countries, insures bank loans for both exporting companies and their buyers. EKN issues a guarantee and pays all compensation.

\subsubsection{The case of Brazil}

ApexBrasil is a government-controlled Brazilian trade and investment promotion agency dedicated to promoting Brazilian exports abroad. Apex-Brazil plays a leading role in attracting Foreign direct investment (FDI) to Brazil. To promote the competitiveness of Brazilian companies, Apex-Brazil provides services in several areas: market research and analysis; training, advice and assistance aimed at increasing the competitiveness and promoting an export culture in companies, preparing them for the challenges of the international market; helping them to create an internationalization strategy; image promotion through international business partners; investment attraction. Investment attraction activities aim to promote transfer of innovative technologies to Brazilian companies as well as organization of working visits. 


\subsubsection{The case of Poland}

The Investor and Exporters Helpdesk (COIE) is the Polish government's main export promotion body. Export support is provided by Foreign Trade Offices; Polish Chamber of Commerce; Polish Investment and Trade Agency; Investor assistance centres; Polish Agency for Enterprise Development; Regional investor and exporter helpdesks; Polish Exporters Association; Polish Chamber of Commerce for importers, exporters and cooperation, etc.

The COIE consists of 15 support points located throughout the country, which provide free advice to entrepreneurs in various ways: assistance in establishing contacts with foreign entrepreneurs; providing databases with information on foreign contractors; assistance in establishing contacts with foreign entrepreneurs; distribution conditions abroad for Polish entrepreneurs who are interested in exporting.

\subsection{The case of TPO Latvia}

In Latvia, you can find more than 10 non-governmental organizations of different sectors which work on export promotion, however, non-governmental organizations represent a certain and narrow sector. Comprehensive export promotion in the country is the task of the government. The Ministry of Economics (MoE) is the leading Latvian public administration institution in the field of economic policy, and is the responsible institution that develops and implements export promotion and foreign investment attraction policy. The Latvian Investment and Development Agency (LIAA) and the holder of state capital shares in the joint stock company "Development Finance Institution Altum" are the most important institutions under the MoE, which support and promote the export of Latvian companies.

\subsubsection{Latvian Investment and Development Agency (LIAA)}

One of the goals of LIAA is to promote the competitiveness and export capacity of Latvian companies in international markets as well as to promote the attraction of foreign investments. In step with global trends, LIAA promotes foreign trade, where it attracts investments, invites entrepreneurs looking for markets abroad, supports those who are just taking first steps in business, encourages the establishment of new contacts in trade missions, national stands, contact exchanges, individual visits and attend export seminars. Even LIAA takes care of the development of regulatory enactments favourable to the business environment and a stable tax policy, as well as the availability of qualified labour, infrastructure and support tools. LIAA has 15 business incubators in the regions of Latvia and economic representative offices located in both EU countries and third countries around the world. Every year, LIAA organizes educational seminars, master classes, business and tourism forums as well as many other events, in which it discusses the current issues of the business environment, motivates to focus on entrepreneurship and updates the services offered by the organization.

\subsubsection{The ALTUM}

The National Development Finance Institution (ALTUM), which provides financing through financial instruments (loans, guarantees, investments in venture capital funds, etc.) in areas identified as important and supportable by the state and in areas where sufficient funding from credit institutions is not available. Latvian and EU funding is used for the implementation of the programs. The ALTUM guarantee package covers $90 \%$ of the buyer's risk, $95 \%$ of the political risk up to 2 years. The maximum amount of ALTUM indemnity for losses incurred with one foreign buyer is 2 million. EUR. 


\subsubsection{The $\mathrm{LCCl}$}

The Latvian Chamber of Commerce and Industry (LCCI) supporting entrepreneurs for export, provides professional advice on export opportunities around the world, as well as additional advice can be provided by colleagues from interested market countries. In order to meet foreign entrepreneurs in person, LCCI organizes business meetings in Latvia and abroad. LCCI encourages exporters to check the reliability of foreign partners and compliance with Latvian and international legislation, including the requirements set by commercial banks.

\subsection{Latvia's GDP and exports}

Gross Domestic Product (GDP) in the period from 1996 to 2019, the first significant increase in GDP was observed in the amount of $6.4 \%$ in 1997 . Latvia's GDP systematically increased its annual growth rate in the period from 1999 to 2006. During this period, the economy developed, the society began to trust financial instruments, which encouraged the society to borrow money and participate in the development of the economy. It is significant that in 1999 Latvia was invited and thus Latvia began the process of joining the EU. This shows that Latvian society looked at the EU with great confidence, hoping to reveal it with the greatest opportunities and growth of the national economy.

With Latvia's accession to the EU in 2004, the public continues to trust the government's intentions and in 2006 GDP will have reached the highest growth rate in several years, reaching $10.7 \%$ in 2005 , and even $11.9 \%$ in 2006 . GDP growth is $8.3 \%$. With the onset of the global crisis, Latvia suffered significantly and already in 2008 experienced an unprecedented decline in GDP of $-3.3 \%$, but in $2009-14.2 \%$. From 2010 onwards, there has been an explosion in GDP, correcting the effects of the crises with an increase of $9.7 \%$ compared to 2009, but in the following year 2011 - rising by $10.8 \%$. Between 2012 and 2019, there have been no significant fluctuations in GDP growth, ranging from $1.9 \%$ to $4.3 \%$ per year, which cannot be considered as significant, but rather as a moderate economic recovery.

In 2005 the share of exports in GDP was 30.2\%. Due to the relatively rapid growth of GDP between 2006 and 2008, the export-to-GDP ratio fell to $25.4 \%$ in 2007 . In the period from 2008 to 2019, as the Latvian economy recovered moderately, with some fluctuations, GDP grew. Although the contribution of exports to GDP has also increased, it is not so significant in relation to the increase in GDP. However, the growth of exports of goods and services in relation to GDP has doubled from 6.7 billion euros in 2009 to 12.8 billion euros in 2019 , which could be seen as a significant contribution to Latvia's growth.

\section{Conclusions}

1. The population of Latvia continues to decline. Taking advantage of global opportunities, Latvia has the chance to increase its export earnings, which will have a positive impact on the country's GDP. This, in turn, may affect the stay of the population in the country as well as the re-emigration of emigrants and improve of the demographic situation.

2. Export promotion is an important set of export support that stimulates and helps exporting companies to increase their export sales.

3. In a seemingly accessible export market in a global environment, beginners are often disappointed when starting to export, a number of conditions are not taken into account: information on potential buyers and their habits, supply characteristics of potential markets, taxes and customs costs, competitors' technologies, equipment and management systems, etc. 
4. Developing countries and small countries rely on some TPOs, which can be explained by low GDP levels. In contrast, high-GDP countries can invest much more in promoting exports than small economies.

5. Reasons for TPO failure: legacy of import substitution policy; lack of attention to supply problems at the company level; insufficient financial structures, lack of funds and low donor influence; inefficient service delivery mechanisms; poor location; insufficient human resources; lack of long-term intervention; deficiencies in design and process; poor advice and insufficiently trained advisers as well as the rigidity of government procedures on expenditure; wrong adaptation and wrong strategy; insufficient attention to commercially provided services.

6. National TPO units must be located around the world and be staffed by professional and high-quality and forward-looking staff who provide comprehensive and attentive services.

7. The TPOs of the countries assessed in the study are both governments and public organizations with a worldwide network of departments. The number of these separate structural units stems from public finance capacity. The TPO provides comprehensive support to both those who are just starting to export and those who are already in export markets.

8. A modern TPO, with adequately funded and trained staff, provides exporters with commercial information, conducts necessary market research and exporter training, assists in licensing and certification procedures, seeks outlets, organizes foreign local exhibitions and meetings with stakeholders, assists international contracts, assists in product packaging and design development as well as in administrative processes; provides comprehensive investment support, export risk insurance against political and commercial risks and performs regular and accurate control over the provided export support to the client.

9. There are two most important state subordinate organizations in Latvia, LIAA and ALTUM and they do everything necessary to support exports. In Latvia, in parallel with state institutions, there are more than 10 different public organizations. One of the most important public organizations is LCCI, which, among other things, encourages exporters to check the reliability of foreign partners and compliance with Latvian and international legislation.

10. Assessing the direct impact of export promotion on GDP, it can be concluded that no convincing data have been obtained on the services provided by TPOs in the respective years. In order to obtain such data, it is necessary to conduct an in-depth study for this purpose. It is necessary to identify the annual reports of all services provided by Latvian TPOs and public organizations performing similar tasks and the contribution of the exporters of specific services to GDP.

\section{References}

1. Eurostat. Retrieved from: https://ec.europa.eu/eurostat/tgm/table.do?tab=table\&plugin= 1\&language $=$ en $\&$ pcode $=$ tps 00001

2. Priede, J. (2010). Doctoral thesis. Latvijas tautsaimniecības nozaru eksporta kvalitātes konkurētspējas analīze. Retrieved from: https://luis.lu.lv/pls/pub/luj.fprnt?1=1\&fn= F1579539379/Janis\%20Priede\%202010.pdf

3. Malca, O., Peña-Vinces, J., Acedo, F.J. (2020). Export promotion programmes as export performance catalysts for SMEs: insights from an emerging economy. Small Business Economics, 55, 831-851. 
4. Hatzigeorgiou, A., Lodefalk, M. (2019). Migration and servicification: Do immigrant employees spur firm exports of services? The World Economy, 3368-3401.

5. Xiang, H. (2020). Facilitating Inclusive Global Trade: Evidence from a Field Experiment. Management Science, 66(4), 1737-1755.

6. Ribeiro, J., Figueiredo, A., Forte, R. (2020). Export Promotion Programs: Differences between Advanced and Emerging Economies. Journal of East-West Business, 26(3), 213-234.

7. Catanzaro, A., Teyssier, C. (2020). Export promotion programs, export capabilities, and risk management practices of internationalized SMEs. Small Business Economics, Early Access: June 2020.

8. Olarreaga, M., Sperlich, S., Trachsel, V. (2020). Exploring the Heterogeneous Effects of Export Promotion. The World Bank Economic Review, 34(2), 332-350.

9. Octavian-Liviu Olaru. (2014). Trade Promotion Organizations (TPOs) Role in Laying the Groundwork for an Export Promotion Program. Global Economic Observer, 2(1), 163-169.

10. Jordana, J., Volpe, M. C., Gallo, A. (2010). Export promotion organizations in Latin America and the Caribbean: An institutional portrait. IDB Working Paper Series, No. IDB-WP-198, International American Development Bank (IDB), Washington, DC, Retrieved from: https://www.econstor.eu/handle/10419/115392

11. Keesing, D.B., Singer, A., Hogan, P. (1991). The role of support services in expanding exports of industrial products in developing countries. Economic Development Institute, World Bank.

12. Exposito, A. (2019). Sanchis-Llopis, Juan A. The effects of innovation on the decisions of exporting and/or importing in SMEs: empirical evidence in the case of Spain. Small Business Economics, 55, 813-829.

13. Schembri, J., Tang, Y. K., Fletcher, M., Dimitratos, P. (2019). How do European trade promotion organisations manage their stakeholders? International Business Review, 28(6), Art. No. 101595.

14. Monreal-Pérez, J., Geldres-Weiss, V.V. (2020). A configurational approach to the impact of trade fairs and trade missions on firm export activity. Business Research Quarterly, 23, 1-19.

15. Yakushev N.O. (2020). Improving the tools for assessing and managing export activities of SMEs in the region. Economic and Social Changes: Facts, Trends, Forecast, Journal section "Issues of management in territorial systems", 13(3), 143-157. 